\title{
Rob Potential in the Coastal City of Kupang, East Nusa Tenggara (NTT)
}

\author{
Suprabadevi Ayumayasari Saraswati ${ }^{*}$, Lumban Nauli Lumban Toruan ${ }^{1}$, Yulianto \\ Suteja $^{2}$, Dadang Karmen ${ }^{3}$ and Putu Eddy Purna Wijaya ${ }^{3}$ \\ ${ }^{1}$ Study Program of Aquatic Resource Management, Faculty of Marine Science and Fisheries, \\ Cendana University, Jl. Adisucipto, Penfui, Maulafa, Kota Kupang, East Nusa Tenggara 85001, \\ Indonesia \\ ${ }^{2}$ Marine Science Department, Marine Science and Fisheries Faculty, Udayana University, Jl. Raya \\ Campus Unud Jimbaran, Kuta Selatan, Badung, Bali 80361, Indonesia \\ ${ }^{3}$ Minister for Public Works and Human Settlements, BBWS Citarum, Jl. Inspeksi Cidurian Sukarno \\ Hatta STA, Cipamokolan, Bandung, West Java 40292, Indonesia
}

*Correspondence :

suprabadevi@staf.undana.ac.id

Received : 2020-11-28

Accepted : 2021-08-09

Keywords :

Rob flood, Kupang City, Impact

\begin{abstract}
Coastal areas are dynamic and vulnerable to environmental changes, both due to natural processes and human activities, the coastal waters in Kupang City are strategic in supporting the development of the economic sector. Coastal areas have unique characteristics, both in terms of bio-geophysics and social, economic and cultural aspects. Some have a high level of vulnerability to global warming. The high value of vulnerability is inseparable from the geomorphological conditions of Kupang City in the form of sandy beaches and coastal erosion. This condition caused Kupang City to become one of the areas affected by tidal flooding. This research is a preliminary study which aims to determine the potential for rob in the coastal city of East Nusa Tenggara that occurred in February 2014. The impact of the tidal floods submerged residents' houses above the knees of adults as high as $70 \mathrm{~cm}$.. The results of this study were to determine the potential for tidal reoccurrence in the city of Kupang, NTT based on tidal forecasting data. Based on the results of the analysis using the Admiralty method, it was found that the Formzhal (F) value for the coast of Kupang City was 25.82, the position of the lowest water level at Oesapa 2 Beach was $206.9 \mathrm{~cm}$, while the sea level elevation position reached the highest peak on Kelapa Lima 2 Beach, namely 478, $5 \mathrm{~cm}$. The value of the harmonic analysis results from the coastal area of Kupang City has HHWL (Highest High Water Level) which is $340.09 \mathrm{~cm}$, the MSL (Mean Sea Level) value is $212.07 \mathrm{~cm}$, and LLWL (Lowest Low Water Level) is $73.36 \mathrm{~cm}$ based on these results. The Kupang coast has the potential for tidal flooding.
\end{abstract}

\section{INTRODUCTION}

Kupang City is a municipality and also the capital city of East Nusa Tenggara province. The geographical location of Kupang City is at $10^{\circ} 36^{\prime} 14^{\prime \prime}-10^{\circ} 39^{\prime} 58^{\prime \prime}$
South Latitude and $123^{\circ} 32$ '23"$123^{\circ} 37^{\prime} 01^{\prime \prime}$ East Longitude with an area of $180.27 \mathrm{Km}^{2}$. The northern border is bordered by Kupang Bay, east by Kupang 
Regency, west by Semau Strait, while in the south by Kupang Regency. The Coastal Area of Kupang City has erosion problems that erode and damage existing coastal protection buildings in the form of stone masonry sea walls. This happens because of the wave factor that continues to hit the existing coastal protection structure and also the seawall structure is not equipped with a toe-protective structure, resulting in scouring at the base of the structure due to the run-up and run-down processes of the waves (Suprijanto and Putra, 2017).

Tidal flooding is an event where sea water rises to inundate the surrounding land, causing environmental problems. The lack of handling and security of the coast makes the condition of the area prone to natural disasters. Haryono and Narni (2004) stated that Rob is a flood that occurs due to tidal sea water inundating land/areas that are lower than the average sea level (mean sea level). Tidal inundation can last for days, even a week and continuously with inundation height varies with the force of gravity, where water will flow to the lowest area and fill the entire space in the lower part. This natural phenomenon causes sea water to inundate some low places (Ali, 2010).

This study aims to examine the potential for tidal flooding in the Kupang City area. The scope of the area is the coastal area of Kupang City which consists of Namosain Beach, Pasir Panjang Beach, Kelapa Lima Beach, Oesapa Beach, and Nunsui Beach. The information obtained from this study can be used by the Kupang City government as a mitigation effort in disasters against tidal flooding due to the influence of sea tides that occur on the Coastal Coast of Kupang City.

\section{METHODOLOGY}

\section{Place and Time}

This research was conducted on 1630 May 2014 in Namosain Beach, Pasir Panjang Beach, Kelapa Lima Beach, Oesapa Beach, and Nunsui Beach.

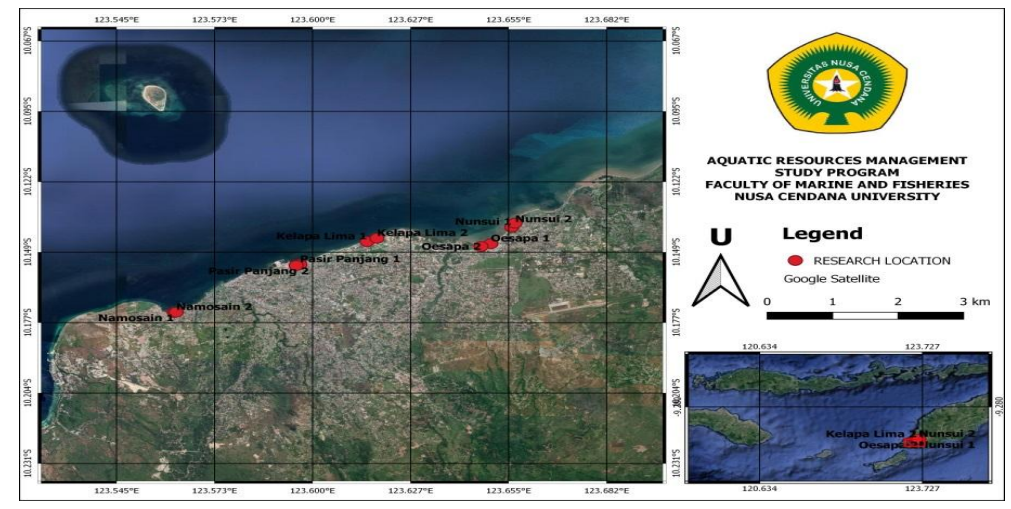

Figure 1. Research area.

\section{Research Materials}

Primary data collection is carried out by conducting direct reviews and data collection, using measuring signs or often called Peil scale. The results of observations on measuring signs are recorded on the tidal water elevation recording form that has been provided. Secondary data uses interviews with the community at the research location to determine the impact of the tidal wave and the adaptation of the community to the tidal flood.

\section{Research Design}

This research used a descriptive method. Research with this method is not intended to test certain hypotheses, but only describes a situation or phenomenon (Arikunto, 2007). So, in this study, we want to know the potential for tidal flooding due to the influence of sea tides that occur on the coast of Kupang City. The data collection method used in this 
study was by observation (observation) secondary data was carried out through interviews with the community in the coastal community of Kupang City.

\section{Work Procedure}

Tidal observations are carried out by visually reading sea level on measuring signs or often called peil scale with a scale interval of $1 \mathrm{~cm}$. The results of observations on measuring signs are recorded in the tidal water elevation recording formula. The results of the observation of the topographical measurements are shown in Figure 1. Setting the zero-elevation position of the measuring sign using a water pass. So that the measurements of topography, bathymetry, and tides have the same datum (reference plane). (Shukla et al., 2017; Zakaria, 1997).

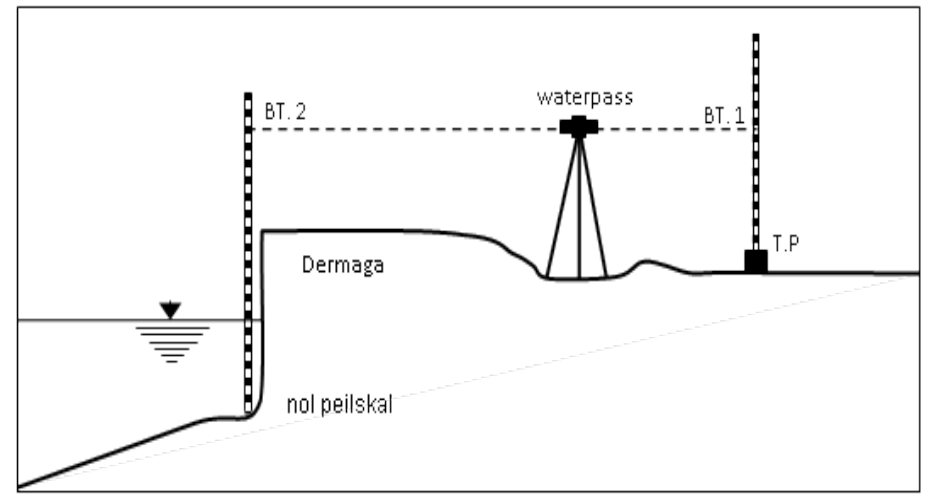

Figure 2. Peil scale binding or leveling.

\section{Data Analysis}

Analysis of the observed data for 30 days was then analyzed to obtain tidal parameters at the location. Calculation of tidal constituents is carried out using the Least Square method. Next is the tidal forecast for the selected 30 days along with the measurement period. The forecasting results are compared with the elevation readings in the field to see their suitability. The results of this forecast are read to determine important tidal elevations. According to Ongkosongo and Suyarso (1989). The tidal type is determined using the Formzhal formula in the following form:

$\mathrm{NF}=\frac{\mathrm{K}_{1}+\mathrm{O}_{1}}{\mathrm{M}_{2}+\mathrm{S}_{2}}$

Where:

$\mathrm{NF}=$ Number Formzhal

$\mathrm{Kl}=$ The tidal component amplitude the main singular caused by the force pull the moon and sun

$\mathrm{O} 1=$ The tidal component amplitude the main singular caused by the force pull the moon
M2 = The tidal component amplitude the main double caused by the force pull the moon

S2 $=$ The tidal component amplitude the main double caused by the force pull the sun

The classification of tidal properties is:

$\mathrm{F} \leq 0,25 \rightarrow$ double pairs

$0,25 \leq \mathrm{F} \leq 1,50 \rightarrow$ mixed pairs (double dominant)

$1,50 \leq \mathrm{F} \leq 3,00 \rightarrow$ mixed pairs (single dominant)

$\mathrm{F}>3,00 \rightarrow$ single pairs

\section{RESULTS AND DISCUSSION}

The variation of tidal amplitude in the bay waters comes from four physical processes, namely the resonance of standing waves from reflections of incoming waves at high tide, frictional effects, geometric convergence (reduction of cross-sectional area towards the coast), and inertia effects. Resonance and convergence of coastal geometry cause an increase in tidal amplitude much larger than the tide in the open sea. The results of the determination of tidal constants are the amplitude and phase of this tidal 
component which can then determine the prediction of tidal elevation (Khatimah et al., 2016). Based on the tidal component, the value of the position of sea level is obtained. The length of the observation data period has an important effect on the calculation process to obtain the number of tidal components. (Arifiyanto et al., 2016).

Table 1. Tidal constituents.

\begin{tabular}{ccc}
\hline Tidal constituents & Information & Period (hour) \\
\hline $\mathrm{M}_{2}$ & Principal lunar & 12.24 \\
$\mathrm{~S}_{2}$ & Principal solar & 12.00 \\
$\mathrm{~N}_{2}$ & Larger lunar elliptic & 12.66 \\
$\mathrm{~K}_{2}$ & Luni-solar semi diurnal & 11.97 \\
$\mathrm{~K}_{1}$ & Luni-solar diurnal & 23.93 \\
$\mathrm{O}_{1}$ & Principal lunar diurnal & 25.82 \\
$\mathrm{P}_{1}$ & Principal solar diurnal & 24.07 \\
$\mathrm{M}_{4}$ & & 6.21 \\
$\mathrm{MS}_{4}$ & & 6.10 \\
\hline
\end{tabular}

Based on the results of the analysis using the Admiralty method, the Formzhal (F) value of the coast of Kupang City is 25.82 so that the tidal type found on the Coast of Kupang City, NTT, can be classified into mixed tidal types which tend to be double daily, because according to the classification of tidal types, the value of $0.25<\mathrm{F}<1.5$ is a mixed tidal type skewed to the double daily. The results of the acquisition of the tidal component show a period value that is closer to the tidal component proposed by (Oyamada, 1989). The longer the data used, the better the quality of the observation data, because the indication of the period value is more precise with the amplitude value. The longer the observation data used, the longer the longperiod tidal component produced. (Hasanudin et al., 2016).

Table 2. Important tidal elevations.

\begin{tabular}{ccc}
\hline Position & \multicolumn{2}{c}{ Elevation $(\mathrm{cm})$} \\
\cline { 2 - 3 } Water face & Peil scale & MSL $=0$ \\
\hline HHWL & 340,09 & 132,24 \\
MHWS & 340,09 & 132,24 \\
MHWL & 392,41 & 73,83 \\
MSL & 212,27 & 0,00 \\
MLWL & 132,56 & $-75,50$ \\
MLWS & 73,36 & $-133,73$ \\
LLWL & 73,36 & $-133,73$ \\
\hline
\end{tabular}

Table 3. Description of the name of the position of the water level.

\begin{tabular}{cc}
\hline & Important Elevation Tides \\
\hline HHWL & Highest high water level \\
MHWS & Mean high water spring \\
MHWL & Mean high water level \\
MSL & Mean sea level \\
MLWL & Mean low water level \\
MLWS & Mean low water spring \\
LLWL & Lowest low water level \\
\hline
\end{tabular}

Data and information regarding sea level elevation is one of the important characteristics of waters because by knowing the dynamics of the water level, 
various information on the physical condition of the waters can be known, namely water level height and long period of time (Trenggono et al., 2015). Poerbandono and Djunarsjah (2005) that sea level elevation is a very important parameter as reference data for the development of coastal areas and coastal structures. Determination of tidal water level data is carried out using the admiralty method. Harmonic analysis calculations using the Admiralty method obtained values for each component in table 2. Processing using the Admiralty method produces sea level elevation data, such as HHWL (Highest High Water Level), MSL (Mean Sea MSL Level), and LLWL (Lowest Low Water). levels). From the processing, the HHWL value is 340.09 $\mathrm{cm}$, the MSL value is $212.07 \mathrm{~cm}$, and the $\mathrm{LLWL}$ is $73.36 \mathrm{~cm}$.

Table 4. Beach elevation on each beach.

\begin{tabular}{llcl}
\hline \multirow{2}{*}{ Location } & \multicolumn{1}{c}{ X $(\mathrm{m})$} & $\mathrm{Y}(\mathrm{m})$ & $\begin{array}{c}\text { Clevation } \\
(\mathrm{cm})\end{array}$ \\
\cline { 2 - 3 } & $561.513,236$ & $8.875 .432,556$ & $+281,5$ \\
Namosain I & $561.571,427$ & $8.875 .441,829$ & $+336,5$ \\
Namosain II & $565.354,899$ & $8.877 .483,160$ & $+302,5$ \\
Pasir Panjang I & $565.242,000$ & $8.877 .438,000$ & $+320,5$ \\
Pasir Panjang II & $567.410,770$ & $8.878 .460,680$ & $+345,5$ \\
Kelapa Lima 1 & $567.710,24$ & $8.878 .604,972$ & $+478,5$ \\
Kelapa Lima II & $571.184,406$ & $8.878 .362,723$ & $+250,2$ \\
Oesapa I & $570.890,007$ & $8.878 .246,315$ & $+206,9$ \\
Oesapa II & $571.829,540$ & $8.879 .076,447$ & $+376,7$ \\
Nunsui I & $571.927,033$ & $8.879 .245,842$ & $+359,0$ \\
Nunsui II & & & \\
\hline
\end{tabular}

Elevation measurements were determined based on tidal forecasts in May 2014, where the elevation position of Namosain Beach I was $281.5 \mathrm{~cm}$, Namosain II was $336.5 \mathrm{~cm}$, Pasir Panjang I was $302.5 \mathrm{~cm}$, Pasir Panjang II was 320.5 $\mathrm{cm}$, Kelapa Lima 1 is $345.5 \mathrm{~cm}$, Kelapa Lima 2 is $478.5 \mathrm{~cm}$, Oesapa 1 is $250.2 \mathrm{~cm}$, Oesapa 2 is $206.9 \mathrm{~cm}$, Nunsui I is $376.7 \mathrm{~cm}$ and Nunsui II is $359.0 \mathrm{~cm}$. The lowest water level elevation at Oesapa Beach 2 is $206.9 \mathrm{~cm}$, while the sea level elevation reaches the highest peak at Kelapa Lima Beach 2, which is $478.5 \mathrm{~cm}$. Based on the results of elevation measurements in table
4, that several locations experience different inundation heights. The results of the measurement of the elevation of Kelapa Lima 2 Beach have the potential for tidal flooding to occur. The sea level elevation values for each location are different (Table 4), indicating that the coastal sea level of Kupang City has changed due to natural conditions. Waves play an important role in determining the water level, because of the shoaling effect. (CERC, 1984) Requires a longer length of tidal data for more valid data to determine the recurrence of tidal inundation in the Coastal City of Kupang.

Table 5. Results of admiralty harmonic analysis.

\begin{tabular}{|c|c|c|c|c|c|c|c|c|c|}
\hline & M2 & S2 & N2 & K2 & K1 & $\mathrm{O} 1$ & P1 & M4 & MS4 \\
\hline $\begin{array}{l}\text { Ampl } \\
\text { (cm) }\end{array}$ & 68.49 & 41.70 & 8.83 & 6.10 & 32.10 & 17.50 & 22.43 & 0.03 & 0.04 \\
\hline $\begin{array}{l}\text { Fasa }( \\
\left.{ }^{0}\right)\end{array}$ & -47.16 & 117.46 & -63.01 & 80.79 & 143.91 & 95.93 & -52.53 & -79.5 & 85.73 \\
\hline
\end{tabular}

According to the classification of tidal types based on the Formzhal value where the value is $0.25<\mathrm{F}<1.5$, then the type of tidal in the coastal waters of
Kupang City is mixed tide which tends to double daily. The tidal type of the waters of Kupang City was analyzed through admiralty calculations for tidal data for the 
waters of Kupang City from 16-30 May 2014. The results of the tidal constituent forecasting that had been obtained were then compared with the tidal data from field observations. Comparison of forecasting data and field observations shown in table 1 , which have similarities in the pattern of the occurrence of tidal cycles, namely two high tides and two low tides in a day. However, the arrival time of changes in the tidal cycle and the water level elevation is different. The time of arrival of the tides and the tides of the forecasting data is one hour earlier than the observation data, but still occurs on the same day.

The results of the analysis of tidal harmonics in the waters of Kupang City can be seen in table 5 , while the type of tidal in the waters of Kupang City can be determined directly through the pattern of tidal cycles which are more dominated by two cycles of tides and low tides in one day with a period and elevation of the face. different highs and lows. Based on the calculation of tidal observation data using the Admiralty method, the mean sea level (MSL) has a value of $0.0 \mathrm{~cm}$, while HHWL and LLWL have elevation values of 340.09 and $73.36 \mathrm{~cm}$, respectively. According to the tidal observation data presented in Table 2, it is known that the highest sea level (HHWL) is known. According to Diposaptono et al. (2009), one of the parameters that affect the tidal inundation area other than sea level rise is the height of the ground. The sloping ground height has an effect on the formation of tidal inundation, so that if the land height is lower than sea level at high tide, the sloping area will be inundated (Prasetyo et al., 2009). The coastal area of Kupang City is classified as a hilly area, the slope of which is around $20-60 \%$ is a hilly area and $0-20 \%$ is a plain.) Based on the model suitability test between the tidal data from the forecasting results and the data. The monthly MSL, HHWL and LLWL are as presented in Table 2.

The monthly MSL, HHWL and LLWL values that have been obtained are then used as a reference in determining the
2014 MSL, HHWL and LLWL values. The annual HHWL and LLWL values are 85, respectively. $73 \mathrm{~cm}$ and $0.04 \mathrm{~cm}$. High tide rises can cause permanent basis or episodic. Areas with ups and downs large ones are very vulnerable to high risks permanent. The area is also vulnerable to periodic flooding (Radjawane et al., 2009).

Factors that support the occurrence of tidal waves due to the increasing conditions of the earth's atmosphere have an impact on all lines of life. Sea level rise (Sea Level Rise) is one of the impacts of global warming which affects coastal life (Sukhla et al., 2017). The increase in the temperature of the earth's atmosphere causes the melting of the volume of ice at the poles, resulting in a rise in sea level. This can be proven by the sea level of around $0.19 \mathrm{~m}$ between 1900 and 2010 with a value of about 1.7 millimeters per year (Church et al., 2013). According to the IPCC (Intergovernmental Panel on Climate Change) report at the end of the 21st century, there will be a global sea level rise of 0.52-0.98 m.

Based on the results of interviews with the community, the community in general states that so far in their area there has been damage to the coastal area. The damage that occurs is in the form of erosion and erosion due to strong waves on the coast of Kupang City. The most severe erosion mainly occurs during the West monsoon which runs between November - April every year. According to the majority of the community, the cause of erosion in the study area is a natural process. In general, the community stated that several efforts to repair the damage to the beach had been carried out, but because the buildings were rotten and there was wave overtopping due to the lack of a high level of existing coastal protection structures. The community in general strongly supports the government's plan to deal with coastal damage, provided that the proposed treatment does not interfere with the activities and interests of local residents, including fishing. In addition to improving 
the beach, the community also wants other facilities that if possible can support their activities as fishermen.

\section{CONCLUSION}

According to the classification of tidal types based on the Formzhal value where the value is $0.25<\mathrm{F}<1.5$, then the tidal type in the coastal waters of Kupang City is mixed tides, which tend to be double daily. The mean sea level (MSL) has a value of $0.0 \mathrm{~cm}$, while HHWL and LLWL have elevation values of 340.09 and $73.36 \mathrm{~cm}$, respectively. Based on the results of interviews with the people of the coastal area of Kupang City, there has been damage to the coastal area. The coastal city of Kupang has the potential to be affected by the tidal disaster.

The damage that occurs is in the form of erosion due to strong waves on the coast of Kupang City.

\section{ACKNOWLEDGMENT}

Thanks to SATKER BWS Nusa Tenggara II KemenPUPR. We also thanks to the research team for the assistance and support during the running of this research.

\section{REFERENCES}

Ali, M., 2010. Kerugian bangunan perumahan akibat rob dan arah kebijakan penanganannya di Kelurahan Bandarharjo Kota Semarang. Thesis, Universitas Diponegoro, Semarang.

Arifiyanto, A., Pranowo, W.S., Fatoni, K.I. and Kuswardani, A.R.T.D., 2016. Pengolahan dan penyajian data arus pasang surut hasil pengukuran acoustic doppler current profiler (ADCP) SonTek Argonout-XR menggunakan perangkat lunak T_Tide_V1.3beta. Jurnal Hidropilar, 2(1), pp.59-70. http://dx.doi.org/1 0.37875/hidropilar.v2i1.43

Arikunto, S., 2007. Prosedur penelitian suatu pendekatan praktek edisi revisi VI, Rineka Apta, Jakarta, p.134.
CERC, 1984. Shore protection manual, Department of the ARMY, Waterways Experiment Station, Corps of Engineers, Coastal Engineering Research Center, Washington DC.

Church, J.A., Clark, P.U., Cazenave, A., Gregory, J.M., Jevrejeva, S., Levermann, A., Merrifield, M.A., Milne, G.A., Nerem, R.S., Nunn, P.D., Payne, A.J., Pfeffer, W.T., Stammer, D. and Unnikrishnan, A.S., 2013, 'Sea level change', in: Stocker, T. F., Qin, D., Plattner, G.-K., et al. (eds), Climate change 2013: The physical science basis. Contribution of working group I to the fifth assessment report of the intergovernmental panel on cimate change, Cambridge University Press, Cambridge; New York, pp.11371216.

Diposaptono, S., Budiman, and Agung, F., 2009. Menyiasati perubahan iklim di wilayah pesisir dan pulau - pulau kecil. https://kkp.go.id/djprl/jaskel /artikel/16472-menyiasati-perubah an-iklim-di-wilayah-pesisir-dan-pula u-pulau-kecil

Haryono and Narni, S., 2004. Karakteristik pasang surut laut di Pulau Jawa. Jurnal Forum Teknik, 28(1), pp.1-5. https://jurnal.ugm.ac.id/mft/articl e/view/1071

Hasanudin, M., Kusmanto, E. and Budisetyawan, W., 2016. Amplifikasi pasang surut dan dampaknya terhadap perairan Pesisir Probolinggo. OLDI (Oseanologi dan Limnologi di Indonesia), 1(3), pp.69-80. http://d x.doi.org/10.14203/oldi.2016.v1i3. 72

Khatimah, H., Jaya, I. and Atmadipoera, A.S., 2016. Software Development of Motiwali (tide gauge) For Tidal Constituents Analysis. Jurnal Kelautan Nasional, 11(2), pp.97104. http://dx.doi.org/10.15578/jk n.v11i2.6111

Ongkosongo, O.S.R. and Suyarso, 1989. Pasang surut. Lembaga Ilmu 
Pengetahuan Indonesia Pusat Penelitian dan Pengembangan Oseanologi, Jakarta, p.257

Oyamada, Y., 1989. Group Training Course in Nautical Charting Conducted by the Hydrographic Department of Japan. The International Hydrographic Review.

Poerbandono and Djunarsjah, E., 2005. Survey hidrografi. Refika Aditama, Bandung, p.166

Prasetyo, L.B., Kartodihardjo, H., Adiwibowo, S., Okarda, B. and Setiawan, Y., 2009. Spatial model approach on deforestastion of Java Island, Indonesia. Journal of integrated field science, 6, pp. 37-44. http://dx.doi.org/10.4018/978-160960-619-0.ch018

Radjawane, I.M., Hadi, S. and Krishnasari, A., 2009. Identification of coastal vulnerabilities to sea level rise in North Jakarta. Relative sea level rise and vulnerability coastal areas and small islands in Indonesia: Status report research Results, BRKP, Jakarta.

Shukla, J.B., Verma, M. and Misra, A.K., 2017. Effect of global warming on sea level rise: A modeling study. Ecological Complexity, 32, pp.99110. https://doi.org/10.1016/j.eco com.2017.10.007

Suprijanto, H. and Putra, S.M.B., 2017. Teknik Pantai. Universitas Brawijaya Press.

Trenggono, M., Priyono, B., Agustiadi, T., Rahman, M.A. and Sukadana, G.P., 2015. Bunga rampai operasional oseanografi di Indonesia memperingati satu dekade Balai Penelitian dan Observasi Laut 20052015. Balai Penelitian dan Observasi Laut, Badan Penelitian dan Pengembangan Kelautan dan Perikanan. Jembrana, pp.39-47.

Zakaria, A., 1997. Kajian awal mengenai kesalahan peramalan pasang surut. Thesis. Institut Teknologi Bandung, Bandung. 